\title{
Telling the truth on yellow rain
}

\section{The State Department is sticking to its allegation that yellow rain in South-East Asia is proof of Soviet use by proxy of biological weapons. To pay attention to other explanations would be more prudent.}

PROFESSOR Matthew Meselson of Harvard University made a brave attempt last week to place the yellow rain controversy on a scientific footing. Judging by the swift - and disparaging - reaction from the US State Department, he appears to have failed. The loser, sad to say, is the State Department itself. What Meselson did was to make public the suggestion that yellow rain may have a natural explanation. In so doing, he challenged the State Department to substitute reason for faith in its contention that yellow rain is a toxin weapon manufactured by the Soviet Union and used by Soviet allies against resistance fighters in South-East Asia and Afghanistan.

The State Department apparently chose faith. For more than a year now, it has maintained that intelligence reports, refugees' stories and - most persuasively - chemical analyses point to Soviet use of toxin weapons. Analyses of environmental samples, whose specific origins have never been adequately documented, show the presence of fungal toxins known as tricothecene mycotoxins - "unequivocal evidence", the State Department says, of weapons use. If the State Department is right, it means that the Soviet Union is guilty of violation not only of humanitarian standards but also of two treaties forbidding the use of chemical warfare or even the possession of toxin weapons.

Meselson's theory begs the State Department to take a more critical look at its "unequivocal evidence"; the State Department's failure to do so only casts new doubts on its credibility. Meselson's idea, which he presented publicly at last week's meeting of the American Association for the Advancement of Science (and which was reported in Nature 5 May, p.3) is that the yellow spots containing tricothecene found on leaves and rocks from South-East Asia are at least initially the work of bees. Bees excrete large amounts of pollen when they leave the hive and Meselson has even collected such samples from a parking lot at Harvard. He has been led to his hypothesis that yellow rain may be pollen-laden bees' excrement by several reports in the past year of the discovery of pollen in samples of yellow rain. Nobody says that this hypothesis rules out the toxin weapon hypothesis, and indeed the occurrence of mycotoxins in samples of yellow rain remains to be explained. One possibility is that natural bees' excrement has been contaminated by weapons toxin, another that the material is a natural substrate for the growth of naturally occurring Fusarium fungi. Meselson takes no position on these alternatives. His demand is merely that all explanations of the phenomenon of yellow rain should be seriously investigated.

\section{Argument}

The State Department's response so far has been shabby - to dismiss Meselson's argument as the "great bee caper". It must be particularly embarrassing for the State Department that Meselson, a respected student of all governments' policies on chemical and biological weapons, should be the one now seeking to help it understand how science should be done. The department has responded in the same way to other evidence recently brought to light: either the evidence has been dismissed or it has been welcomed as further proof of Soviet treachery. The first reports of pollen in yellow rain were thus greeted with the prejudiced opinion that pollen must have been deliberately added to make toxins more easily inhaled and so more effective. Last week's comment on Meselson's argument that there may be a natural explanation of yellow rain shows that prejudice can lead to blindness: the State Department's opinion that a natural explanation is ruled out because the quantities of toxin found in yellow rain would be lethal to bees entirely misses the point that, on Meselson's hypothesis, toxins would be found (or accumulated) only after the bees had excreted the pollen.

\section{Evidence}

In presenting his theory last week, Meselson went through the exercise of listing where the evidence supports his theory and where it contradicts it. The State Department seems not to have taken the hint; nor did it admit that it should define the areas where questions remain. But there is a host of unanswered questions. How widespread is the phenomenon? Does it occur in parts of South-East Asia remote from battle areas? Which Fusarium species are native to the region? Does the pollen in the samples vary from region to region? From season to season? Is it consistent with the vegetation of the region? Why is there such a diversity of pollen in the samples found? Do bees feed on such a diversity of plants? These are the sorts of questions the State Department should be asking if it is to preserve any credibility on this issue.

The tragedy is that the State Department has impaled itself on a hook from which it cannot escape by making public serious charges of Soviet perfidy before these could have been sustained by evidence. Politically, it would not be acutely embarrassing to have to admit that some of the data are in dispute. By discarding objectivity, the State Department has now laid itself open to the charge that it is more anxious to sustain its publicity campaign on yellow rain than to search for the truth. Although Meselson's hypothesis was communicated to government of ficials more than a month ago (Nature, ibid.), the department threw together its intemperate response only when he made the notion public. To judge from what State Department spokesmen have been saying, Meselson's hypothesis is regarded as a threat, not as a legitimate question.

The State Department is also putting out a line that has become increasingly apparent as new questions have arisen about the scientific data - the assertion that the case that yellow rain is a toxin weapon rests not only on scientific evidence but on intelligence data. This is disingenuous. The State Department knows as well as anybody that such credence as its allegations against the Soviet Union have so far won derives from the way in which anecdotal evidence from South-East Asia has been fortified by what purports to be objective evidence. The United Nations investigation in South-East Asia and that mounted separately by the Canadian Government have underlined the difficulty of making sense of what is said (often in an obscure dialect of a foreign language) by politically displaced persons sheltering in refugee camps. The Yellow Rainmakers, a book by Grant Evans, an Australian sociologist (Verso Editions), provides an explanation of these difficultics - that of the peculiar social structure of the Hmong population against whom the present government of Laos has taken up embittered cudgels. The State Department cannot now rest its case on this flimsy evidence without, in effect, acknowledging that the allegations originally put forward in 1981 by then Secretary of State Alexander Haig, but repeated last year by his successor Mr George Shultz, appear increasingly insubstantial. 